BUDGETING : Journal of Business, Management and Accounting

Volume 1, Nomor 2, Juni 2020

e-ISSN: $2715-2480$

p-ISSN: $2715-1913$

DOI : https://doi.org/10.31539/budgeting.v1i2.1238

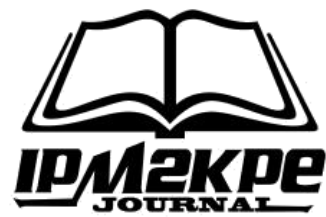

\title{
PENGARUH KOMPENSASI DAN DISIPLIN KERJA TERHADAP KINERJA KARYAWAN
}

\author{
Yulandri $^{1}$, Onsardi ${ }^{2}$ \\ Universitas Muhammadiyah Bengkulu ${ }^{1,2}$ \\ ydri5005@gmail.com ${ }^{1}$
}

\begin{abstract}
ABSTRAK
Tujuan dari penelitian ini adalah untuk mengetahui pengaruh kompensasi dan disiplin kerja terhadap kinerja karyawan pada PT (SBS) Sinar Bengkulu Selatan. Metode penelitian dalam penelitian ini menggunaka metode penelitian kuantitatif. Hasil penelitian dapat disimpulkan bahwa persepsi responden tentang Lokasi Kompensasi (X1) dan Disiplin Kerja (X2) mempengaruhi Kinerja Karyawan (Y) dengan hasil regresi linier berganda diperoleh persamaan berikut: $\mathrm{Y}=14.876+0,277 \mathrm{X} 1+0,795 \mathrm{X} 2$ analisis korelasi $\mathrm{R}=0,823(\mathrm{X} 1-\mathrm{Y}), 0,926(\mathrm{X} 2-\mathrm{Y})$ dan koefisien detrminasi $\mathrm{R} 2=0,521$ atau sekitar $(52,51 \%)$ melalui pengujian hipotesis bersama (secara bersamaan) dan individual (parsial) dalam penelitian ini menggunakan uji f dan uji t, kompensasi (X1) dan disiplin kerja $(X 2),=0,000$. Simpulan, terdapat pengaruh yang signifikan kompensasi dan disiplin kerja terhadap kinerja karyawan pada PT (SBS) Sinar Bengkulu Selatan.
\end{abstract}

Kata Kunci: Disiplin Kerja, Kinerja Karyawan, Kompensasi

\section{ABSTRACT}

The purpose of this research is to study compensation and work discipline on employee performance at PT (SBS) Sinar Bengkulu Selatan. The research method in this study uses quantitative research methods. The results of the study can be concluded regarding the respondents' perceptions about Compensation Location (X1) and Work Discipline (X2) Employee Performance results $(Y)$ with the results of multiple linear regression obtained the following research results: $Y=14.876+0.277 X 1+0.795 X 2$ analysis of responses $R=0.823(X 1)-Y), 0.926(X 2-Y)$ and the coefficient of determination $R 2=$ 0.521 or approximately (52.51\%) through testing the hypotheses together (simultaneously) and individuals (partial) in this study using the $f$ test and $t$ test, compensation (X1) and work discipline (X2), =0,000. Conclusion, significant significant contribution and work discipline to employees at PT (SBS) Sinar Bengkulu Selatan.

Keywords: Work Discipline, Employee Performance, Compensation

\section{PENDAHULUAN}

Peranan Sumber Daya Manusia memiliki kedudukan yang sangat penting dan strategis di dalam organisasi untuk mencapai tujuan. Sumber daya manusia sangat penting bagi perusahaan dalam mengelola, mengatur, dan memanfaatkan karyawan, sehingga dapat berfungsi secara produktif untuk tercapainya tujuan perusahaan. Sumber 
Daya Manusia sebagai penggerak organisasi dalam mencapai tujuannya, maka upayaupaya organisasi dalam mendorong karyawan untuk bekerja lebih baik harus terus dilakukan dengan adanya karyawan-karyawan yang bekerja secara baik ini, maka di harapkan hasil kerja (kinerja karyawan) yang baik juga tercapai oleh karyawan dalam melaksanakan tugasnya sesuai dengan tanggung jawab yang diberikan kepadanya.

PT.(SBS) Sinar Bengkulu Selatan merupakan perusahaan yang bergerak dibidang agribisnis atau yang lebih tepatnya perusahaan tempat pengelolaan minyak mentah kelapa sawit. Perusahaan ini memiliki lahan sekitar 300 hektar kebun kelapa sawit perusahaan tersebut merupakan perusahaan yang didirikan pada tahun 2011.Kelebihan perusahaan ini adalah perusahaan ini berfokus pada pengeloalaan minyak mentah,sehingga buah kelapa sawit yang segar dapat dikelola dengan baik dengan perusahaan sehingga menghasilnya minyak mentah yang berkualitas.Perusahaan ini dipilih karena memiliki jarak yang tidak terlalu jauh dengan alamat penulis dan penulis banyak mendengar cerita dari karyawan yang bekerja diperusahaan ini. Perusahaan ini sepenuhnya milik perseorangan dan bertujuan untuk menghasilkan minyak mentah yang baik dan berkualitas yang selanjutnyaakan dikirim pabrik pusatuntuk dikelola menjadi minyak jadi. Apabila dilihat dari produktifitasnya, perusahaan ini sudah cukup terbilang baik hanya saja masih terdapat beberapa kekurangan yang terjadi di dalamnya.Dari informasi yang diperoleh dari karyawan PT.(SBS) Sinar Bengkulu Selatan, dapat diketahui bahwa kinerja karyawan pada perusahaan ini masih memiliki beberapa kelemahan antara lain karyawan disini masih kurangnya pemberiankompensansi yang diberikan kepada karyawan,kurangnyadisiplin waktu, bisa menyebabkan kinerja karyawan tersebut sangat rendah.

Pemberian kompensasi merupakan salah satu pelaksanaan fungsi manajemen sumber daya manusia yang berhubungan dengan semua jenis pemberian penghargaan individual sebagai pertukaran dalam melaksanakan tugas keorganisasian. Pemberian kompensasi haruslah adil dan layak bagi seorang karyawan. Artinya adil dan layak adalah bahwa sedapat mungkin kompensasi atau gaji yang diterima kelangsungan hidup karyawan dan pemberian kompensasi itu harus pula berdasarkan pada dasar kecilnya tanggung jawab dan risiko dari masing-masing pekerjaan sehingga dapat meningkatkan kinerja karyawan (Keraf, 2000; Tangkilisan, 2005; Tanjung, 2005). 
Menurut Rivai (2008) disiplin kerja adalah suatu alat yang digunakan para manajer untuk berkomunikasi dengan karyawan agar mereka bersedia untuk mengubah sesuatu perilaku serta sebagai suatu upaya untuk meningkatkan kesadaran dan kesediaan seseorang menaati semua peraturan perusahaan dan norma-norma sosial yang berlaku.Disiplin kerja pada karyawan sangat dibutuhkan, karena apa yang menjadi tujuan organisasi akan sukar dicapai bila tidak ada disiplin kerja. Kedisiplinan merupakan fungsi operatif manajemen sumber daya manusia yang terpenting karena semakin baik disiplin pegawai, semakin Berdasarkan survei lapangan, peneliti menemukan adanya kekurangan menaati tata tertib, ketentuan-ketentuan perusahaan yang telah di tetapkan pihak perusahaan tetapi masih terjadi pada karaywan PT.(SBS) Sinar Bengkulu Selatan, seperti masih banyak karyawan yang mangkir kerja dengan berbagai alasan, berkeliaran pada saat jam kerja dan tingkat keterlambatan karyawan yang cukup tinggi.

Hasil dari survei awal menunjukkan bahwa tingkat kedisplinan karyawan pada PT.(SBS) Sinar Bengkulu Selatan masih perlu diperbaiki terlihat pada bulan agustus sebanyak 10 orang izin 3 orang sakit dan 20 orang alfa menunjukan bahwa tingkat kedisplinan karyawan di PT.(SBS) Sinar Bengkulu Selatan sangtlah rendah sehingga menyebabkan kinerja karyawan yang ada di PT.(SBS) Sinar Bengkulu Selatan menurun, pada bulan september tingkat absensi karyawan PT.(SBS) Sinar Bengkulu Selatan menurun 7 orang izin 1 orang sakit dan 23 orang alfa sehingga tingkat kedisplinan karyawan PT.(SBS) Sinar Bengkulu Selatan meningkat dibandingkan dengan bulan agustus yang lalu. Sedangkan pada oktober 15 orang izin 4 orang sakit dan 15 orang alfa. Hal ini merupakan indikasi masih rendahnya kinerja karyawan tersebut.

Berdasarkan permasalahan dan hasil penelitian terdahulu yang menunjukan hasil yang berbeda-beda maka penulis tertarik untuk mengadakan penelitian lebih lanjut dalam penelitian ini yang akan mengangkat judul "Pengaruh Kompensansi Dan Displin Kerja Terhadap Kinerja Karyawan Pada PT. SBS Bengkulu Selatan.”

\section{KAJIAN TEORI}

\section{Deskripsi Konseptual}

Kinerja karyawan merupakan suatu yang dinilai dari apa yang dilakukan oleh seorang karyawan. Dalam kerjanya dengan kata lain, kinerja individu adalah bagaimana 
seorang karyawan melaksanakan pekerjaannya atau untuk kerjanya. Kinerja karyawan yang meningkat akan turut mempengaruhi atau meningkatkan prestasi organisasi sehingga tujuan organisasi yang telah ditentukan dapat dicapai. Kinerja karyawan (prestasi kerja) adalah hasil secara kualitas dan kuantitas yang dicapai oleh seseorang karyawan dalam melaksanakan tugasnya sesuai dengan tanggung jawab yang diberikan kepadanya (Mangkunegara, 2010, Onsardi, 2019). Lebih lanjut bahwa kinerja itu adalah unjuk kerja karyawan pada suatu perusahaan yang merupakan pencerminan loyalitas mereka dimana mereka bekerja (Asmawi, M., 2017, Anjani, R., 2019, Onsardi, O, 2018)

Menurut Mangkunegara (2009) indikator untuk mengukur kinerja karyawan adalah: Kualitas, Seberapa baik seorang karyawan mengerjakan apa yangseharusnya dikerjakan. Kuantitas, Seberapa lama seorang pegawai bekerja dalam satu harinya. Kuantitas kerja ini dapat dilihat dari kecepatan kerja setiap pegawai itu masing-masing. Pelaksanaan Tugas, Seberapa jauh karyawan mampu melakukan pekerjaannya dengan akurat atau tidak ada kesalahan. Tanggung jawab, Kesadaran akan kewajiban karyawan untuk melaksanakan pekerjaan yang diberikan perusahaan.

Kompensansi merupakan bentuk balas jasa untuk karyawan yang di berikan kepada perusahaan. Menurut Rivai (2008) kompensasi lasngsung terdiri dari pembayaran karyawan dalam bentuk upah, gaji, bonus atau komisi. Kompensasi langsung disebut upah dasar yakni upah atau gaji tetap yang seorang pekerja dalam bentuk upah bulanan (salary) atau upah mingguan atau upah tiap jam dalam bekerja (hourly wage)".

Menurut Simamora (2004), indikator untuk mengukur kompensasi karyawan diantaranya sebagai berikut:

\section{Upah dan gaji}

Upah adalah basis bayaran yang seringkali digunakan bagi para pekerja produksi dan pemeliharaan. Upah pada umumnya berhubungan dengan tarif gaji per jam dan gaji biasanya berlaku untuk tarif bayaran tahunan, bulanan atau mingguan.

\section{Insentif}

Pengertian Insentif adalah tambahan kompensasi di atas atau di luar gaji atau upah yang diberikan oleh perusahaan. 


\section{Tunjangan}

Pengertian Tunjangan adalah asuransi kesehatan dan jiwa, program pensiun, liburan yang ditanggung perusahaan, dan tunjangan lainnya yang berkaitan dengan hubungan kepegawaian.

\section{Fasilitas}

Pengertian Fasilitas adalah pada umumnya berhubungan dengan kenikmatan seperti mobil perusahaan, akses ke pesawat perusahaan, tempat parkir khusus dan kenikmatan (baca: perlakuan khusus) yang diperoleh karyawan.

Disiplin adalah sikap seseorang atau kelompok yang berniat untuk mengikuti aturan aturan yang telah ditetapkan. Dalam kaitannya dengan pekerjaan, pengertian disiplin kerja adalah suatu sikap dan tingkah laku yang menunjukkan ketaatan karyawan terhadap peraturan organisasi. Disiplin merupakan tindakan manajemen untuk mendorong para anggota organisasi memenuhi tuntutan berbagai ketentuan tersebut (Siagian, 2012).

Rivai (2008) menyatakan indikator yang dapat digunakan untuk mengkaji disiplin kerja pegawai adalah:

\section{Ketepatan Waktu Hadir dalam Bekerja}

Hal ini menjadi indikator yang mendasar untuk mengukur kedisiplinan, dan biasanya karyawan yang memiliki disiplin kerja rendah terbiasa untuk terlambat dalam bekerja.

\section{Ketaatan terhadap Standart Kerja}

Hal ini dapat dilihat melalui besarnya tanggung jawab karyawan terhadap tugas yang diamanahkan kepadanya.

\section{Kepatuhan terhadap Peraturan}

Karyawan yang taat pada peraturan jam kerja tidak akan melalaikan prosedur kerja dan akan selalu mengikuti pedoman kerja yang ditetapkan perusahaan.

\section{Tingkat Kewaspadaan}

Karyawan memiliki kewaspadaan tinggi akan selalu berhati-hati, penuh perhitungan dan ketelitian dalam bekerja, serta selalu menggunakan sesuatu secara efektif dan efisien. 


\section{Bekerja Etis}

Beberapa karyawan mungkin melakukan tindakan yang tidak sopan ke pelanggan atau terlibat dalam tindakan yang tidak

\section{METODE PENELITIAN}

Penelitian ini dilakukan di PT.(SBS) Sinar Bengkulu Selatan yang beralamatkan di JL. Desa Nanjungan Kecamatan Pino Raya Kabupaten Bengkulu Selatan. Waktu yang digunakan dalam penelitian ini dari 15 Desember 2019 - 5 Januari 2020.

Metode penelitian yang dipakai dalam penelitian ini menggunakan metode kuantitatif. Data diambil dari karyawanPT.(SBS) Sinar BengkuluSelatan, melalui kuesioner.

Populasi dalam suatu penelitian merupakan kumpulan individu atau obyek yang merupakan sifat-sifat umum. Penulis menetapkan populasi dalam penelitian ini adalah karyawan PT.(SBS) Sinar Bengkulu Selatan sejumlah 123 karyawan.

Dalam penelitian ini metode yang digunakan dalam pengambilan sampel menggunakan rumus Slovin yaitu sebagai berikut:

$$
n=\frac{N}{1+\mathrm{Ne}^{2}}
$$

Dimana:

$\mathrm{n} \quad=$ Jumlah sampel

$\mathrm{N} \quad=$ Jumlah populasi

E $=$ Kelonggaran ketidaktelitian karena kesalahan pengambilan sampel yang dapat ditoleransi (5\%).

Penelitian ini menggunakan tingkat keandalan 90\% karena menggunakan tingkat kelonggaran ketidaktelitian sebesar 5\%. Apabila dilakukan perhitungan menggunakan rumus, maka jumlah minimum yang di peroleh adalah:

$$
n=\frac{N}{1+\mathrm{Ne}^{2}}=\frac{123}{1+123 \cdot 0,05^{2}}=94,0726
$$

Maka sampel dibulatkan menjadi 95 orang. Sampel yang akan diambil dari populasi menggunakan convenience sampling, yaitu istilah umum yang mencakup variasi luasnya prosedur pemilihan responden. Convenience sampling merupakan pengumpulan informasi dari anggota populasi yang dengan senang hati bersedia 
memberikannya. Pengambilan 95 sampel yaitu dengan memberikan dan menjelaskan mengenai kuesioner pada karyawan.

Metode Analisis Regresi Linier Berganda Metode analisis kuantitatif, yaitu metode multivariate analysis yang menggunakan perhitungan statistik yang dianalisis menggunakan program SPSS versi 24. Adapun metode analisis yang digunakan dalam penelitian ini adalah regresi berganda, digunakan untuk mengetahui pengaruh kompensansi (X1), dan displin kerja (X2), terhadap kinerja $(\mathrm{Y})$ dengan rumus: $\mathrm{Y}=$ $\mathrm{b} 1 \mathrm{X} 1+\mathrm{b} 2 \mathrm{X} 2$ Keterangan: $\mathrm{b} 1=$ Koefisien Variabel X1 b2 = Koefisien Variabel $\mathrm{X} 2 \mathrm{~b} 3=$ Koefisien Variabel $\mathrm{X} 3 \mathrm{X} 1=$ Variabel pengaruh kompensansi $\mathrm{X} 2=$ Variabel pengaruh displin kerja $\mathrm{Y} \quad=$ Variabel terhadap pengaruh kinerja karyawan.

Koefisien Deterninasi Untuk mengukur besarnya persentase pengaruh kompensansi (X1), dan displin kerja (X2), terhadap kinerja (Y) digunakan alat analisis koefisien determinasi.

Pengujian Hipotesis Pengujian hipotesis pengaruh kompensansi (X1), dan displin kerja (X2), terhadap kinerja (Y) secara keseluruhan (simultan), digunakan uji F. Cara pengujian adalah membandingkan nilai $\mathrm{F}$ hitung dengan $\mathrm{F}$ tabel pada tingkat keyakinan $95 \%$ atau alpha $=0.05 .1)$ Jika $\mathrm{F}$ hitung $<\mathrm{F}$ tabel, maka kompenansi $(\mathrm{X} 1)$, dan displin kerja (X2) tidak berpengaruh secara simultan terhadap kinerja (Y). 2) Jika F hitung > F tabel, maka kompenansi (X1), dan displin kerja (X2) berpengaruh secara simultan terhadap kinerja (Y). Untuk menguji apakah kompensansi (X1), dan displin kerja (X2), berpengaruh secara parsial terhadap kinerja (Y) digunakan uji t (t-test). Cara pengujian adalah membandingkan nilai probabilitas t hitung pada tingkat keyakinan 95\% atau $\alpha=0.05$. 1) Apabila probabilitas t hitung t hitung $>0,05$, artinya secara parsial yaitu masingmasing variabel kompensansi (X1), dan displin kerja (X2) tidak berpengaruh terhadap kinerja (Y). 2) Jika probabilitas t hitung t hitung $<0,05$, artinya secara parsial yaitu masing-masing variabel kompensansi (X1) dan displin kerja (X2) berpengaruh terhadap kinerja $(\mathrm{Y})$.

\section{HASIL PENELITIAN}

\section{Regresi Berganda $Y=0,277 X 1+0,795 X 2$}

Dari analisis regresi linear berganda diperoleh persamaan $Y=14.876+0,277$ $\left(\mathrm{X}_{1}\right)+0.795\left(\mathrm{X}_{2}\right)$ angka ini mempunyai makna nilai konstanta 14.876 mempunyai arti bahwa variable kompensansi $\left(\mathrm{X}_{1}\right)$ dan displin kerja $\left(\mathrm{X}_{2}\right)$ terhadap kinerja karyawan $(\mathrm{Y})$ 
pada PT.(SBS) Sinar Bengkulu Selatan sama dengan nol, maka variable kinerja akan tetap yaitu, 14.876. hal ini berlaku saat dilaksanakan penelitiaan. Koefisien regresi variable kompensansi $\left(\mathrm{X}_{1}\right)$ dan displin kerja $\left(\mathrm{X}_{2}\right)$, sebesar 0,277 dan 0,795 dan mempunyai makna bahwa apabila displin kerja $\left(\mathrm{X}_{2}\right)$ ditingkatkan, maka akan meningkatan kinerja karyawan (Y) pada PT.(SBS) Sinar Bengkulu Selatan.

Berdasarkan pengolahan data primer yang didapat dengan menggunakan program SPSS didapat koefisien determinasi $(\mathrm{R} 2)=52,51 \%$. Nilai koefisien determinasi tersebut mempunyai arti bahwa variasi perubahan kinerja karyawan dapat dijelaskan oleh variabel kompensansi (X1), dan displin kerja (X2) sebesar 52,51\%, sedangkan sisanya 47,9\% merupakan sumbangan variabel lain yang tidak diteliti. Tingginya nilai sumbangan variabel kompensansi (X1), displin kerja(X2) terhadap kinerja karyawan (Y), karena PT.(SBS) Sinar Bengkulu Selatan benar-benar melakukan kompensansi kepada karyawannya, dan karyawan juga memiliki displin kerja yang baik.

Uji F Uji F dilakukan untuk mengetahui apakah variabel independen atau variabel bebas kompensansi (X1), dan displin kerja (X2) berpengaruh secara simultan atau bersama-sama terhadap variabel dependen kinera karyawan (Y). Pengujian yang menggunakan uji F dengan signifikan $\alpha(0,05)$ atau 5\%. Dari tabel 4.13, dapat diketahui bahwa sig $\mathrm{F}=0,000<\alpha=0,05$ dengan nilai $\mathrm{F}$ hitung sebesar 50.091 sedangkan $\mathrm{F}$ tabel sebesar 1.9855. Dengan demikian F hitung lebih besar dari F tabel. Hal ini menunjukan bahwa semua variabel independen yaitu pkompensansi (X1), dan displin ker (X2) secara bersama-sama berpengaruh signifikan terhadap kinerja karyawan (Y).

Uji t Uji t dilakukan untuk melihat hipotesis pengaruh dari variabel independen secara parsial kompensansi (X1), dan displin kerja (X2) berpengaruh terhadap kinerja karyawan (Y). Berdasarkan tabel 4.12, maka didapat hasil sebagai berikut:

Untuk variabel kompensansi (X1), dengan taraf signifikan 5\% diperoleh probabilitas $=0,018<\alpha=0,050$ dengan nilai $\mathrm{t}$ hitung $=2.404>\mathrm{t}$ tabel $=1,9860$. Dengan demikian variabel pemberdayaan (X1) berpengaruh terhadap variabel kinerja karyawan. 
Untuk variabel displin kerja (X2) dengan taraf signifikan 5\% diperoleh probabilitas $=0,000<\alpha=0,050$, dengan nilai $\mathrm{t}$ hitung $=6.330>\mathrm{t}$ tabel $=1,9860$ Dengan demikian variabel displin kerja (X2) berpengaruh terhadap variabel kinerja karyawan $(\mathrm{Y})$.

\section{PEMBAHASAN}

Berdasarkan hasil tanggapan karyawan kompensansi PT.(SBS) Sinar Bengkulu Selatan sudah dikatakan baik, Hasil penelitian ini menyatakan bahwa kompensansi yang ada di perusahaan PT. (SBS) Sinar Bengkulu Selatan sudah di katakan baik. hal ini sebabkan oleh pemberiaan gaji dan insentif, serta tunjangan yang sudah di berikan secara tepat waktu sehingga kinerja karyawan yang ada di PT. (SBS) Sinar Bengkulu Selatan lebih meningkat dari sebelumnya dapat di lihat dari hasil tanggapan responden, variabel Kompensasi $\left(\mathrm{X}_{1}\right)$ dengan nilai tertinggi 4.01 dan nilai terendah 3.55 maksudnya adalah responden merasa sistem kompensasi di PT.(SBS) Sinar Benkulu Selatan sudah baik. Dari 10 item pernyataan, item pernyataan nomor 4 (Upah yang di berikan perusahaan sebandig dengan kerja lembur saya) memiliki skor tertinggi yaitu 4,01 dan item pernyataan dengan skor terendah adalah nomor 10 (Saya menerima fasilitas kantor yang memadai) memiliki skor 3,55

Hasil ini menunjukan bahwa displin kerja pada PT.(SBS) Sinar Bengkulu Selatan kategori baik. hal ini disebabkan pergantiaan pimpinan pada PT.(SBS) Sinar Bengkulu Selatan sangat mempengaruhi serta aturan-aturan baru yang di terapkan oleh pihak pimpinan PT.(SBS) Sinar Bengkulu Selatan sehingga kedispilanan yang ada di PT.(SBS) Sinar Bengkulu Selatan sudah di katakan baik dapat dilihat dari hasil tanggapan responden, variabel Disiplin Kerja (X2) berada pada kategori tinggi 4.04 dan yang terendah 3,49 maksudnya adalah responden merasa disiplin kerja karyawan PT.(SBS) Sinar Bengkulu Selatan sudah baik.

hasil penelitiaan ini menyatakan bahwa kinerja karyawan sudah dikatakan baik. hal ini dapat lihat pada karyawan PT.(SBS) Sinar Bengkulu Selatan yang sudah melakukan pekerjaan yang secara tepat waktu serta tugas-tugas yang di limpahkan kepada karyawan sudah terlaksana dengan baik pada perusahaan PT.(SBS) Sinar Bengkulu Selatan sehingga kinerja karyawan sudah mulai meningkat di bandingkan dengan sebelumya. Kemudiaan dapat di lihat dari tanggapan responden, variabel Kinerja Karyawan (Y) berada pada kategori baik dengan nilai tertinggi 4.02 dan 
memilki terendah 3.53, maksudnya adalah kinerja karyawan pada PT.(SBS) Sinar Bengkulu Selatan sudah baik. Dilihat dari 1 (Saya melakukan pekerjaan dengan baik dan 2 (Skill yang saya milki sesuai dengan pekerjaan yang saya lakukan), artinya bahwa Setiap karyawan selalu melakukan pekerjaannya sesuai dengan target dan standar yang telah disepakati oleh pihak perusahaan.

Hasil penelitian ini sejalan dengan penelitiaan Armansyah et al., (2018) menyatakan bahwa secara simultan kompensansi $\left(\mathrm{X}_{1}\right)$ dan displin kerja berpengaruh positif dan signifikan terhadap kinerja karyawan (Y). Hasil penelitian ini sejalan dengan penelitian Mahardika et al., (2016) menyatakan bahwa secara simultan kompensansi $\left(\mathrm{X}_{1}\right)$ dan displin kerja $\left(\mathrm{X}_{2}\right)$ berpengaruh positif dan signifikan terhadap variable kinerja karyawan (Y).

Hasil penelitian ini sejalan dengan penelitian Kurniati (2018 menyatakan bahwa secara simultan kompensansi $\left(\mathrm{X}_{1}\right)$ displin kerja $\left(\mathrm{X}_{2}\right)$ berpengaruh positif dan signifikan terhadap kinerja karyawan (Y).

\section{SIMPULAN}

Kinerja karyawan PT.(SBS) Sinar Bengkulu Selatan Mayora baik. Hal ini terbukti dari hasil kuesioner penelitian yang menunjukkan rerata kinerja karyawan sudah baik. Kompensansi yang di berikan kepada karyawan PT.(SBS) Sinar Bengkulu Selatan sudah dilakukan dengan baik, yaitu adanya pemberian kesempatan dan dorongan kepada para karyawan untuk meningkatkan kinerja karyawan, serta untuk menyelesaikan pekerjaan secara tepat waktu. Displin kerja sudah baik.Hasil ini menunjukan bahwa displin kerja pada PT.(SBS) Sinar Bengkulu Selatan kategori baik. hal ini disebabkan pergantiaan pimpinan pada PT.(SBS) Sinar Bengkulu Selatan sangat mempengaruhi serta aturan-aturan baru yang di terapkan oleh pihak pimpinan PT.(SBS) Sinar Bengkulu Selatan sehingga kedispilanan yang ada di PT.(SBS) Sinar Bengkulu Selatan sudah di katakan baik dapat dilihat dari hasil tanggapan responden, variabel Disiplin Kerja (X2) berada pada kategori tinggi 4.04 dan yang terendah 3,49 maksudnya adalah responden merasa disiplin kerja karyawan PT.(SBS) Sinar Bengkulu Selatan sudah baik. 


\section{DAFTAR PUSTAKA}

Anjani, R. (2019). Tata Kelola Adminitrasi Keuangan, dan Pembangunan Desa Tepi Laut Kabupaten Bengkulu Utara. Jurnal Pengabdian Masyarakat Bumi Raflesia, 2(2)

Armansyah, A., Azis, I., \& Rossanty, E. P. N. (2018). Pengaruh Kompensasi dan Disiplin Kerja terhadap Kinerja Pegawai Kantor BPJS Kesehatan Cabang Palu. Jurnal Ilmu Manajemen Universitas Tadulako, 4(3), 235-244

Asmawi, M. (2017). The Effect of Compensation, Empowerment, and Job Satisfaction on Employee Loyalty. International Journal of Scientific Research and Management, 5(12), 7590-7599

Keraf, G. (2000). Diksi dan Gaya Bahasa. Jakarta: Rinneka Cipta

Kurniati, D. (2018). Pengaruh Kompensasi dan Disiplin Kerja terhadap Kinerja Karyawan di PT. Marinal Indoprima Desa Kapedi Sumenep

Mahardika, P. A. C., Bagia, I. W., \& Yulianthini, N. Y. (2016). Pengaruh Kompensasi dan Disiplin Kerja terhadap Kinerja Karyawan pada Hotel Puri Bagus Lovina. Jurnal Bisma, 4

Mangkunegara, M. (2010). Manajemen Sumber Daya Manusia Perusahaan. Bandung: PT Remaja Rosdakarya

Onsardi, O. (2018). Loyalitas Karyawan pada Universitas Swasta di Kota Bengkulu. COSTING: Journal of Economic, Bussines and Accounting, 2(1), 1-13

Onsardi, O. (2019). Effect of Empowerment on Employees Performance (No. v7g9t). Center for Open Science

Rivai, R., \& Veitzal, V. (2008). Manajemen Sumber Daya Manusia untuk Perusahaan: dari Teori ke Praktik. Jakarta: PT.Rajagrafindo Persada

Siagian, S. (2012). Manajemen Sumber Daya Manusia. Jakarta: Bumi Aksara

Simamora, H. (2004). Manajemen Sumber Daya Manusia. Yogyakarta: STIE YKPN

Tangkilisan, H. N. S. (2005). Pengaruh Kompensasi terhadap Motivasi Kerja Karyawan Bagian Personalia PT Agronesia Divisi Industri Makanan dan Minuman Bandung. Universitas Widyatama

Tanjung, B. N., \& Ardial, A. (2005). Pedoman Penulisan Karya Ilmiah: (Proposal, Skripsi, dan Tesis) dan Mempersiapkan Diri Menjadi Penulis Artikel Ilmiah. Jakarta: Kencana 